Reasumując niniejsze rozważania, książka Franciszka Ziemskiego mimo niewątpliwych zalet, pozostawia w Czytelniku wrażenie sporego niedosytu. Miejmy nadzieje, że kolejne tomy wydawnictwa będą znacznie lepsze, a Autor wystrzeże się sygnalizowanych błędów.

Krzysztof Ratajczak

1 Autor używa przy tym terminu Cesarstwo Niemieckie, odnoszącego się do państwa niemieckiego powstakego po zwycieskiej wojnie z Francja w 1870 r.

2 Zawarte są one choćby w pracy Doroty Zolądź-Strzelczyk, Peregrinatio academica. Studia mlodzieży polskiej z Korony $i$ Litwy na akademiach $i$ uniwersytetach niemieckich $w \mathbf{X V} i$ pierwszej polowie X VI wieku, Poznań 1996; por. taż, Idealy edukacyjne doby staropolskiej, Warszawa 1990.

${ }^{3}$ Podstawową literature przedmiotu podaje ostatnio Leszek Mrozewicz, Historia powszechna. Starożytnośs, Poznań 1999.

4 Por. J. Strzelczyk, Goci-rzeczywistosć $i$ legenda, Warszawa 1984; tenże, Wandalowie $i$ ich afrykańskie państwo, Warszawa 1992.

5 F. Ziemski, Wybrane problemy tradycji $i$ wychowania w polskich dziejach ( $X$ w. $-X V I I$ w.), Katowice 1999, s. 38.
6 Zob. J. Strzelczyk, Po tamtej stronie Odry. Dzieje $i$ upadek Slowian polabskich, Poznań 1968; tenże, Slowianie i Germanie w Niemczech srodkowych we wczesnym śdedniowieczu, Warszawa 1976, tenż, Od Praslowian do Polaków, Poznań 1987. Por. też liczne prace Gerarda Labudy zebrane w tegoż, Polsko-niemieckie rozmowy o przeszlości, Zbiór rozprow i artykulów, Poznań 1996; tu dalsza literatura przedmiotu.

7 Zob. J. Wyrozumski, Welka historia Polski, t. 2, Dzieje Polski piastowskiej ( VII wiek - 1370), Kraków 1999, s. 66-70. Por. także liczne prace Henryka Lowmiańskiego na czele $\mathrm{z}$ monumentalnymi Poczqtkami Polski, t. 1-6, Gerarda Labudy i in.

B J. Ehlers, Domschulen, w: Lexicon des Mittlealters, t. III, München-Zürich 1986, kol. 1226; por. K. Stopka, Szkoly katedralne metropolii gnieźnieniskiej $w$ średniowieczu. Studia nad ksztalceniem kleru polskiego w wiekach średnich, Kraków 1994, s. 10 .

9 J. Topolski, O literaturze $i$ praktyce rolniczej w Polsce na przelomie XVI Dziejow Spolecznych i Gospodarczych" 14 (1952/1953), s. 43-106; tenże, Narodziny kapitalizmu w Europie $X I V-X V I$ wieku, Warszawa 1965; tenże, Gospodarka polska a europejska w XVI-XVI wieku, Poznań 1977; tenże, Polska w czasach nowożytnych. Od środkowoeuropejskiej potegi do utraty niepodleglości (1501-1795), Poznań 1994, tu dalsza literatura.

\title{
Noty
}

\section{Humanistyka przelomu wieków, pod red. Józefa Kozieleckiego, Wydawnictwo Akademickie "Żak", Warszawa 1999, ss. 417}

Schyłek wieku zawsze przynosi ze sobą fale podsumowań, rozliczeń, ocen upływającego czasu. Człowiek ma tendencje do spoglądania w przeszłość przy okazji mijania kolejnych słupów milowych wyznaczających lata, dekady, wieki. Retrospekcja jest tym bardziej zrozumiała, gdy zbliża się ku końcowi milenium. W nurt prac, dla powstania których mijające tysiąclecie stanowiło impuls, wpisuje się niewątpliwie $\mathrm{Hu}$ manistyka przelomu wieków pod redakcją Józefa Kozieleckiego.

Redaktor tomu podzielił zawarte w nim teksty na cztery części. „Część pierwsza - problemowa - poświęcona jest globalnym i lokal- nym dylematom czlowieka, takim jak edukacja, demografia, zdrowie czy religia" (s. 9). Otwiera ją tekst Jerzego Z. Holzera Trzy procesy demograficzne. Tytułowe, najistotniejsze procesy demograficzne, o których pisze Autor to: zwiększanie się liczby ludności świata, zjawisko starzenia się ludności i postępująca urbanizacja.

Wiara $w$ godzinie przelomu ks. Józefa Tischnera to między innymi rozważania na temat zagrożeń wewnętrznych i zewnętrznych, które moga doprowadzić do przecięcia więzi łączących wiernych z Kościołem. Wśród zagrożeń zewnętrznych ks. Tischner odnotowuje „wyzysk religii do celów politycznych". Jest to dla Koś- 
cioła duży problem, gdyż według Autora "katwiej zwalcza się wrogów niż nadgorliwych przyjaciól”, Kościół zaś nie zdążył „nawyknąć do politycznych pieszczot, a dziś to one są jego największą groźbą" (s. 46).

Zbigniew Kwieciński w tekście Edukacja wobec nadziei i zagrożeń wspólczesności stwierdza, że edukacja będąc „, wielką nadzieją współczesności” jest jednocześnie „ogromnie zagrożona, pełna wewnętrznych sprzeczności i niedoceniona" (s. 51).

Kwestie edukacji zajmują też Krzysztola Konarzewskiego - autora tekstu Reforma oświaty przedmiotem dyskursu.

Perspektywy medycyny humanistycznej: leczeni, leczqcy $i$ kontrakt terapeutyczny to przedmiot rozważań Kazimierza Jankowskiego.

Konkluzje kolejnego tekstu (Zaduma nad możliwościq ulepszania czlowieka), tym razem autorstwa Józefa Kozieleckiego, stanowi stwierdzenie, iż „trzeba najpierw próbować wykorzystać swoje wrodzone możliwości i talenty, a gdy metoda samorozwoju nie da wyników, należy przejść do innych strategii, takich jak procedury kulturyzacji - w ostateczności - inżynieria genetyczna" (s. 127).

W drugiej części pracy - spolecznej - Józef Kozielecki umieścił artykuły „zajmujące się jednostką ludzką więziami społecznymi i wspólnota" (s. 9). W tym rozdziale znajdujemy m.in. teksty: Kazimierza Obuchowskiego pt. Rewolucja podmiotów $i$ nowy indywidualizm, Leszka Nowaka - Unifikacja liberalnego i Marksowskiego modelu czlowieka, Marii Jarymowicz - Poznać siebie - zrozumieć innych, Adama Podgóreckiego - Wyjaśnianie $i$ rozwiqzywanie problemów spolecznych. $\mathrm{Ku}$ megasocjologii.

Jerzy Szacki opisuje Klopoty z pojeciem narodu i stwierdza, że „nie ma bodaj drugiego pytania nauk społecznych, na które udzielano by równie wielu sprzecznych odpowiedzi" (s. 150).

Autor kolejnego tekstu (Przyrodniczy i humanistyczny punkt widzenia $w$ badaniach historycznych) - Jerzy Topolski zadaje pytanie, czy historia „skazana jest na opozycję między humanistycznym a przyrodniczym punktem widzenia, tzn. czy musi się toczyć bój o człowieka, o jego miejsce w narracji $\mathrm{i} w$ tym, co niq steruje"? (s. 227). Konkludując J. Topolski stwierdza, iż „oba punkty widzenia sq równouprawnione, podstawowym zaś problemem do rozstrzygnięcia dla badań humanistycznych (nie tylko historycznych) jest powiqzanie obu w konstruowaniu obrazu rzeczywistości społecznej (historycznej)" (s. 227).

Trzecia część książki - kulturowa - „poświęcona została wielości często sprzecznych poglądów na ludzką kulturę" (s. 9). Czytelnik znajdzie tu artykuły: J. Kozieleckiego pt. Trangresje jako źródlo kultury, Zygmunta Baumana - Smierć $i$ nieśmiertelnośc $w$ ponowoczesnym swiecie, Stefana Morawskiego - W Janusowym widnokregu, Leszka Kołakowskiego - Moje wróżby w sprawie przyszlości religii $i$ filozofii, Andrzeja K. Koźmińskiego - Kultura menedżerska i Stanisława Lema - Krótkie uwagi o humanizmie.

Ostatnia, czwarta część pracy „zawiera ważne rozdziały penetrujące świat tekstów, obrazów i wartości" (s. 9). W otwierającym ten fragment książki artykule Nauka o literaturze wśród innych dyscyplin Michał Glowiński prowadzi rozważania na temat stosunku pewnych dziedzin wiedzy (również nauki o literaturze) do innych gałęzi nauki. Autor twierdzi, że nie chodzi tu jedynie o pokrewieństwa czy podobieństwa, gdyż relacje te mogą przybierać inną postać. „(...) dana dyscyplina nie przyjmuje na ogól wyłacznic roli pełnego pokory ubogiego krewnego, czekającego na wspomożenie, ani jedynie roli bogacza, który nic nie czerpiąc od innych, każe wspaniałomyślnie rozdzielać różnorakie dobra" (s. 344).

Poza artykułem M. Głowińskiego czwarty rozdział książki zawiera jeszcze prace: Edwarda Balcerzana - Nowe formy w pisarstwie $i$ wynikajace stqd porozumienia, Stanisława Mossakowskiego - Pitagorejska teoria piękna $i$ jej rola $w$ teoriach artystycznych $i$ naukowych doby humanizmu oraz Jana B. Deręgowskiego - Spotkanie z rzeczywistosciq wirtualnq (dwa ostatnie teksty ilustrowane sq rycinami i fotografiami).

Ewa Kuczyńska 